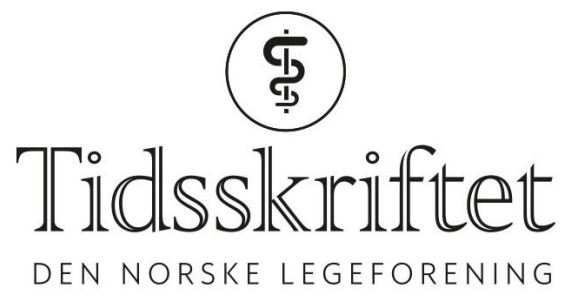

\title{
Det problematiske oddsforholdet
}

MEDISIN OG TALL

\section{MAGNE THORESEN}

E-post: magne.thoresen@medisin.uio.no

Magne Thoresen er professor ved Avdeling for biostatistikk, Oslo senter for biostatistikk og epidemiologi, Universitetet i Oslo.

Forfatteren har fylt ut ICMJE-skjemaet og oppgir ingen interessekonflikter.

Oddsforholdet (OR) er et hyppig brukt mål på sammenheng mellom eksponering og sykdom i medisinske studier. Men hva betyr det egentlig?

I forskningsartikler finner vi utsagn som «det var en signifikant sammenheng mellom eksponering og sykdom $(\mathrm{OR}=2, \mathrm{O}, \mathrm{p}<0,05)$ ). Hva sier imidlertid en $\mathrm{OR}=2,0$ ? Formelt er det enkelt. Det sier at oddsen for sykdom er 2,o ganger høyere blant de eksponerte enn blant de ikke-eksponerte. Problemet er at for de fleste av oss er oddsbegrepet vanskelig å forholde seg til. I praksis blir derfor oddsforholdet ofte fortolket som en relativ risiko (RR), som for de fleste er et mer intuitivt mål på sammenheng. De to målene er imidlertid ikke sammenfallende, og en slik fortolkning kan dermed falle uheldig ut.

\section{Oddsforholdet og relativ risiko}

La oss ta et eksempel: Tenk på en situasjon hvor vi har én gruppe som er eksponert for en gitt risikofaktor, f.eks. røyking, og én gruppe som ikke er eksponert. Anta at risikoen for sykdom er 0,025 blant de ikke-eksponerte mens den er 0,05 blant de eksponerte. Den relative risikoen er forholdet mellom disse to tallene, slik at $\mathrm{RR}=0,05 / 0,025=2,00$. Oddsen for sykdom er definert som risikoen for sykdom delt på (1 - risikoen for sykdom), så oddsen blant de eksponerte er 0,05/o,95, mens oddsen blant de ikke-eksponerte er 0,025/o,975. Oddsforholdet blir da forholdet mellom disse to brøkene. Regner man ut dette, finner man $\mathrm{OR}=2,05$, altså veldig likt $\mathrm{RR}$.

La oss nå tenke oss en situasjon hvor risikoen i de to gruppene er ti ganger høyere, altså o,25 blant de ikke-eksponerte og o, 5 blant de eksponerte. Fortsatt er selvfølgelig RR $=2,00$, men regner vi ut oddsforholdet i denne situasjonen finner vi $\mathrm{OR}=3,00$, altså ganske forskjellig fra RR. Generelt vil alltid oddsforholdet være «sterkere» enn den relative risikoen, tallmessig. Med dette mener vi at OR $>$ RR så lenge eksponeringen $ø$ ker risikoen for sykdom $(\mathrm{OR} / \mathrm{RR}>1)$, mens $\mathrm{OR}<\mathrm{RR}$ i situasjoner hvor eksponeringen har en beskyttende effekt (OR $\mid R R<1$ ). Det er verdt å merke seg at dersom $R R=1$ (altså ingen sammenheng mellom eksponering og sykdom) vil også OR være lik 1, og omvendt (tabell 1). Vi sier ofte at vi kan fortolke OR som RR dersom risikoen (eller sannsynligheten) for sykdom er «liten», typisk sier vi mindre enn $10 \%$. 
Tabell 1

Illustrasjon av forskjell mellom relativ risiko (RR) og oddsforholdet (OR) for forskjellige verdier av sannsynligheten for sykdom blant de eksponerte $\left(p_{1}\right)$ og de ikke-eksponerte $\left(p_{2}\right)$.

\begin{tabular}{|llrr|}
\hline & & RR & OR \\
\hline $\mathrm{p}_{1}=0,1$ & $\mathrm{p}_{2}=0,4$ & 0,25 & 0,17 \\
\hline $\mathrm{p}_{1}=0,01$ & $\mathrm{p}_{2}=0,04$ & 0,25 & 0,24 \\
\hline $\mathrm{p}_{1}=0,1$ & $\mathrm{p}_{2}=0,3$ & 0,33 & 0,26 \\
\hline $\mathrm{p}_{1}=0,01$ & $\mathrm{p}_{2}=0,03$ & 0,33 & 0,33 \\
\hline $\mathrm{p}_{1}=0,1$ & $\mathrm{p}_{2}=0,2$ & 0,5 & 0,44 \\
\hline $\mathrm{p}_{1}=0,01$ & $\mathrm{p}_{2}=0,02$ & 0,5 & 0,49 \\
\hline $\mathrm{p}_{1}=0,01$ & $\mathrm{p}_{2}=0,01$ & 1 & 1 \\
\hline $\mathrm{p}_{1}=0,02$ & $\mathrm{p}_{2}=0,01$ & 2 & 2,02 \\
\hline $\mathrm{p}_{1}=0,2$ & $\mathrm{p}_{2}=0,1$ & 2 & 2,25 \\
\hline $\mathrm{p}_{1}=0,03$ & $\mathrm{p}_{2}=0,01$ & 3 & 3,06 \\
\hline $\mathrm{p}_{1}=0,3$ & $\mathrm{p}_{2}=0,1$ & 3 & 3,86 \\
\hline $\mathrm{p}_{1}=0,04$ & $\mathrm{p}_{2}=0,01$ & 4 & 4,13 \\
\hline $\mathrm{p}_{1}=0,4$ & $\mathrm{p}_{2}=0,1$ & 4 & 6 \\
\hline
\end{tabular}

Som en konsekvens av dette hører man ofte at oddsforholdet ikke kan brukes i situasjoner hvor risikoen er høyere. Dette er imidlertid galt. Selv om oddsforholdet ikke kan fortolkes som en relativ risiko, er det fremdeles et gyldig mål på sammenheng. Det må bare tolkes på en litt annen måte.

\section{Antall syke per friske person}

La oss nå tenke oss at vi beveger oss inn i den ikke-eksponerte populasjonen. Her teller vi opp antall syke og friske, og vi kommer til at for hver tiende friske person vi støter på, treffer vi én syk person. Oddsen for sykdom er da 1/10. Tilsvarende kan vi bevege oss inn i den eksponerte populasjonen. Her teller vi også antall friske og syke og finner at for hver tiende friske person vi støter på, treffer vi to syke. Oddsen for sykdom i denne populasjonen er altså 2/10. Hvis vi nå er interessert i oddsforholdet (eksponert/ikke-eksponert), så er det forholdet mellom disse to tallene, altså 2/10 delt på 1/10, lik 2. Oddsforholdet forteller oss altså hvor mange flere syke vi treffer på per friske person når vi sammenligner den eksponerte og den ikke-eksponerte populasjonen. I dette tilfellet er det dobbelt så mange syke per friske person blant de eksponerte som blant de ikke-eksponerte.

Som for andre statistiske effektmål oppgir man vanligvis oddsforholdet sammen med et $95 \%$ konfidensintervall. Konfidensintervallet gir oss informasjon om hvor presist vi er i stand til å måle sammenhengen mellom eksponering og sykdom. Det kan imidlertid også tolkes som en hypotesetest, og vi konkluderer med at det er en statistisk signifikant sammenheng mellom eksponering og sykdom dersom konfidensintervallet for oddsforholdet ikke inneholder verdien 1.

\section{Hvorfor bruke oddsforholdet?}

Hvorfor bruker vi dette målet på sammenheng når det er så vanskelig å fortolke? Det er i hovedsak to grunner til det. For det første er det enkelte studiedesign (klassiske kasuskontroll-studier) som ikke gir mulighet for å beregne RR, men hvor OR kan beregnes enkelt. For det andre er oddsforholdet det naturlige effektmålet som kommer ut av en av de mest brukte regresjonsmodellene våre, nemlig logistisk regresjon (en regresjonsmodell for binære utfallsvariabler) (1). Det finnes ikke noen regresjonsmodell som på en tilsvarende måte produserer en relativ risiko. 
LITTERATUR:

1. Thoresen M. Logistisk regresjon - anvendt og anvendelig. Tidsskr Nor Legeforen 2017; 137. doi: 10.4045/tidsskr.17.0309. [PubMed][CrossRef]

Publisert: 8. april 2019. Tidsskr Nor Legeforen. DOI: 10.4045/tidsskr.19.0011

(C) Tidsskrift for Den norske legeforening 2020. Lastet ned fra tidsskriftet.no 